\title{
Developing Mechanized Systems for Producing, Harvesting, and Handling Brambles, Strawberries, and Grapes
}

Justin R. Morris

ADDITIONAL INDEX WORDS. abscission layer, fruit maturity, mechanization systems, mechanical harvesting, mechanical shoot positioning, mechanical pruning, processing

Summary. M echanization of harvesting, pruning, and other cultural operations on many small fruit crops for the processing market has occurred in response to the scarcity and expense of hand labor. Scientists at the Arkansas Agricultural Experiment Station and other experiment stations in the $U$ nited States and throughout the world have developed new cultural and fruithandling systems and have determined the effects of these systems on fruit yield and quality. This research has resulted in the development of prototype and commercial machinery as well as production and handling systems that have assisted in mechanization systems for brambles, strawberries (Fragaria xananas D uch.), and grapes (Vitis sp.). M uch of this body of work is in commercial use and much is simply available, awaiting circumstances that will be beneficial to implementation.

$\mathrm{F}$

or some crops, harvest labor accounts for as much as two-thirds of

the total labor costs. Fruit producers generally use hand labor

as long as it is available at a reasonable cost, since mechanization

requires large capital investments and often reduces the producer's flexibility to change from one crop to another. Consequently, the technology for mechanization has usually been developed long before implementation.

$M$ igrant workers have provided much of the harvest labor. U ntil recently, there was little concern for the welfare of these workers by either the employer or the government. Eventually, concern about the problems of the migrant workers resulted in major changes and improvements in wages, housing, education, and health benefits. These developments increased the cost of harvesting and have led to an increased interest in harvest mechanization so that producers can remain competitive and maintain an inexpensive supply of fruit for consumers. This interest in mechanization has brought about developments for producing and harvesting brambles, strawberries, and grapes.

\section{Brambles}

H ARVESTERS. Successful mechanical harvesting systems have been developed for many fruit, with brambles and grapes being outstanding examples.

Distinguished professor, I nstitute of Food Science and Engineering, U niversity of Arkansas, 272 Young Ave, Fayetteville AR 72704. Published with the approval of the D irector, Arkansas Agricultural Experiment Station, manuscript \#9703. The cost of publishing this paper was defrayed in part by the payment of page charges. U nder postal regulations, this paper therefore must be hereby marked advertisement solely to indicate this fact. 
The bramble harvester has, with minor adaptations, been used to pick erect and trellised blackberries (R ubus subg. rubus), black raspberries ( $R$ ubusoccidentalisL.), red raspberries ( $R$ ubusi daeusL.), and gooseberries ( $R$ ibes hirtellum $M$ ichx.). By the mid1960 s, there were $\approx 30$ commercial machines operating in raspberry plantations in the U nited States (D ale et al., 1995). T he prototype developed in 1964 at the U niversity of Arkansas was one of the first harvesters developed and operated by mechanical shaking of the canes (M orris et al., 1978b). The cane fruit develops an abscission layer at maturation, which allowsthemoremature fruit to be harvested when shaken. All modern self-propelled commercial pickers work on this shaking principle using sets of horizontal beaters positioned in a vertical plane on each side of the row (Fig. 1). These improved beater arms on the modern commercial harvesters allow for a reduction in the number of strokes needed per minute to harvest the fruit, and cause the least amount of damage to the new canes compared to the original prototype.

The range of 100 to 150 strokes per minute at a ground speed of $1 \mathrm{mph}$ (1.6 $\mathrm{km} \cdot \mathrm{h}^{-1}$ ) is adequate to harvest only the ripe fruit. This frequency of stroke also providesa complete shaking throughout the hedgerow. This is important, since berries that are allowed to remain in the interior of the hedgerow often develop mold and contaminate the next harvest. M ost self-propelled commercial bramble harvesters should have the feature of being ableto be raised, lowered and leveled to fit the plane of the field and the height of the canes. The need for thiscapability is due to the low fruiting habit of many of the cane fruit crops. The Arkansas harvester collects all fruit above 15.5 inches $(40 \mathrm{~cm})$ and is only one of several successful cane fruit harvesters currently in use. The commercial model of the Arkansas harvester, with one operator and four field graders, can do the work of 80 to 85 handpickers.

FruIT QUALITY. U nlike hand harvesting, machines are able to operate at night to allow for the harvesting of fruit at a lower temperature (M orris et al., 1978b). Research and experience have shown that night harvesting is necessary in warm production regions to maximizefruit quality. Themechanically harvested fruit can be of better quality than hand-harvested fruit when all operations are carried out in a proper and timely manner. $M$ achine-harvested berriesarelarger and have higher total soluble solids, lower acidity, and superior color compared to hand-harvested berries, which generally do not have uniform maturity (M orris et al., 1978b). By machine harvesting at the lowest possible temperature, fruit quality can be maintained during subsequent handling before processing.

T reating brambleswith thegrowth regulator ethephon before harvest can improve the fruit quality. Ethephon reduces the number of required harvests, increases color, and lowers acidity of both raw and processed blackberries (M orris et al., 1978a; Sims and Morris, 1982). M ost insects can be eliminated from canefruit before machineharvesting by following recommended spray programs for specific insect problems. Of those that remain, $95 \%$ can be removed before processing by a washing technique in which infested berries pass through water containing adilutenonalkaline, anionic wetting agent. There is no loss of quality with this method (Crandall et al., 1966; Christensen et al., 1973).

Cultural systems. In many cases, modification so old cultural systems must be made to successfully machine harvest brambles. A mechanical pruner, developed at the $U$ niversity of Arkansas, properly shapes the hedgerow for maximum harvesting efficiency of erect cane fruit (M orris et al., 1978b) and reduces the labor necessary for pruning. 0 ld canes left in the hedgerow, do not affect yield or fruit quality.

$\mathrm{H}$ edgerow culture of erect blackberries is conducive to mechanical harvesting. Five to seven harvests at 4- to 5-d intervals may be required to harvest the entire crop mechanically; therefore, it is desirable to breed for concentrated maturity to reduce the number of harvests. Breeding programs on brambles
Fig. 1. Commercial model of U niversity of Arkansas cane fruit harvester, manufactured and sold by Blueberry Equipment $C_{0 .}$., Inc., South $\mathrm{H}$ aven, Mich.

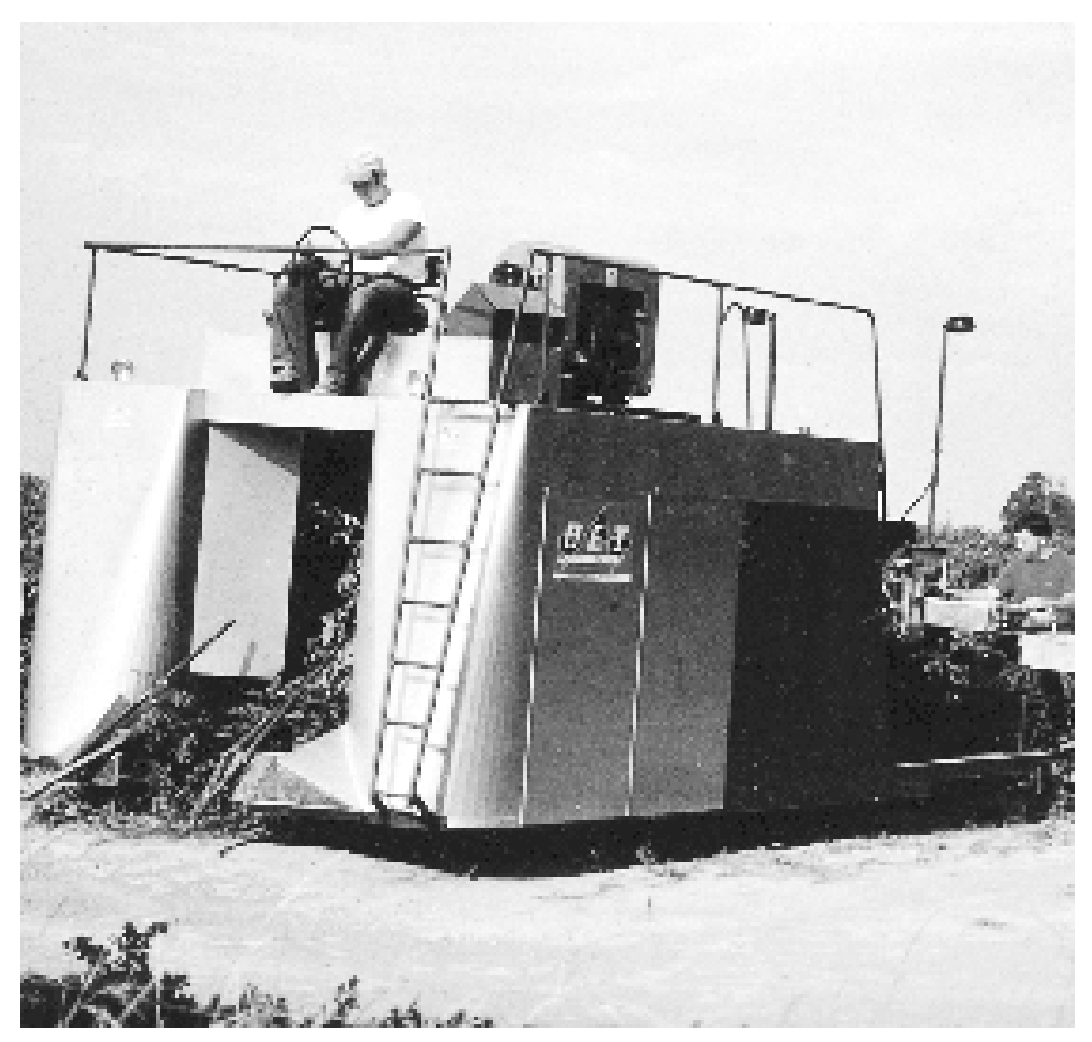


Fig. 2. First commercial single-row mechanical strawberry harvester developed by the U niversity of Arkansas and manufactured by B lueberry Equipment C o., I nc., South H aven, Mich. A two-row harvester was successfully tested and used commercially in Oregon. at someland-grant institutions, at theU SD A, and in Canada have developed cultivars of erect blackberriesthat adapt well to mechanization (M oore, 1979, 1984). T hesebreeding programs remain active and should continue to produce more cultivars better adapted to mechanical harvesting.

Most blackberry plantings need to be renovated after 5 or 6 years. R enovation can be accomplished by mowing the entire hedgerow to 3 to 4 inches ( 8 to $10 \mathrm{~cm}$ ) immediately after the final harvest. All mowed canes should be removed from thefield. A mechanical harvester cannot be used in the year following this renovation. However, the fruit from these shorter vines can be hand harvested if an economical supply of labor is available.

The Pacific N orthwest has adapted well to mechanical harvesting of brambles. G rowers in 0 regon machine harvest most of their 1500 acres ( $600 \mathrm{ha}$ ) of black raspberries and most of 8000 acres (2800 ha) of trailing blackberries and hybrid berries ( $D$ ale et al., 1995). The lack of rain in harvest season in the Pacific N orthwest makes mechanical harvesting feasible. Where rainfall at harvest time is common, harvest days are reduced, and the softer fruit is more easily damaged, as are the primocanes, which then easily succumb to cane death by the fungus Leptosphaeria coriothyrium (Fckl.) Sacc. (D ale et al., 1995).

\section{Strawberries}

At the U niversity of Arkansas, several harvesting principles had to be evaluated in the process of developing a mechanical harvester for strawberries since, historically, strawberries have been considered one of thecrops least adaptable to mechanization (M orris et al., 1978c; N elson and Kattan, 1967; N elson et al., 1978).

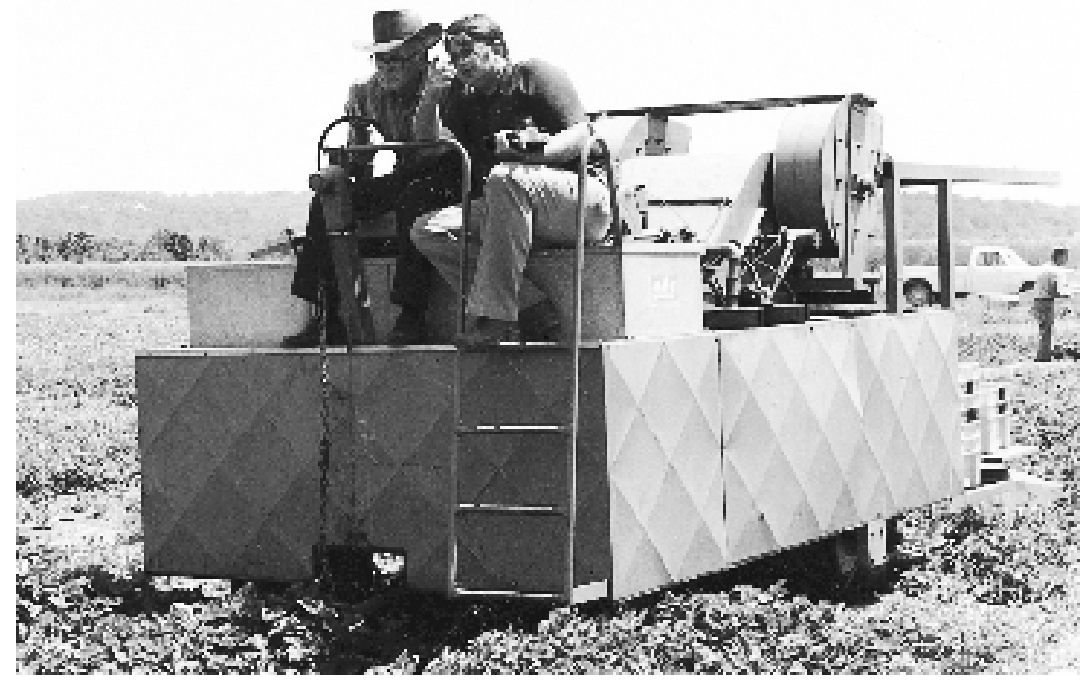

HaRvesters. A tractor-drawn prototype of a mechanical strawberry harvester was developed at theU niversity of Arkansasin 1967, and since then it has undergone continual revision (Fig. 2) including development into a self-propelled machine. This prototype was a stripping harvester. It used a reel with alternating brush and comb that raked through the crop. Air suction lifted the berries and foliage (Fig. 3). An airlock berry removal system evacuated the debris while the berries dropped through the airlock valve onto the conveyor. A grower in Copemish, $M$ ich., purchased thismachineand suggested that it be built to accommodate two rows for better commercial acceptance. Subsequently, Blueberry Equipment $\mathrm{C}$ o., Inc. (BEI), of $M$ ichigan modified and produced the U niversity of Arkansas harvester as a two-row hydraulic-powered machine for commercial sale. I n those early years, researchers working with the harvesters mentioned and other types of mechanical strawberry harvesters reported picking efficiencies from 31\% to $87 \%$ (Denisen and Buchele, 1967), $91 \%$ to $97 \%$ (Morris et al., 1978C), and $24 \%$ to $92 \%$ (Booster et al., 1970a, 1970b; Booster, 1973.)

I $n$ addition to the $U$ niversity of A rkansas harvester, several others have been developed for strawberries. Three different stripping type machines were develo ped in I taly during this same period (D i Ciolo and Zoli, 1975; L ucignani, 1979; R osati, 1980), and researchers in D enmark produced a commercial machine called the $D$ anpluck harvester, which uses 62 -inch-wide $(160-\mathrm{cm})$ rakes on a sloping belt to lift the berries. A uniquefinger reel plucks the leaves from the berries as an air ejector expels them. (Thuesen, 1988).

Q uick and Denison (1970) described a stripping-type harvester that used a bank of diverging, vibrating ramps instead of a reel. Shikaze and Nyborg (1973) developed a variation on this design by replacing the vibrating action with a bank of small belts. $\mathrm{H}$ owever, there has been no commercial use of these machines. M ore recently, $\mathrm{H}$. L ee of theU niversity of Guelph, C anada, and Bragg Enterprises in Canada have developed another version of the stripping harvester (Swinkles and M urray, 1991). T heir machine uses a reel with cam-controlled finger bars that work through the plants, stripping the strawberries from their peduncles and dumping them through the cam mechanism onto a conveyor system.

The British $\mathrm{N}$ ational Institute of Agricultural Engineering developed a mowertypeharvester that was modified by M ichigan State $U$ niversity and then commercialized in somewhat different forms by two machinery companies, Smallford Planters of Silsoe, England, and Conners M achinery, Inc. (CM I), 
of Simcoe, O ntario, Canada ( $\mathrm{H}$ ansen et al., 1983). The Smallford machine used a cutter bar with fingers that lifted the berries above the bar (Kemp, 1976). The berries were conveyed to a belt where cutting blades clipped the trusses, and debris was blown back into the field. The CMI harvester employed a more effectiveairblast system to separatethe debrisfrom the berries and used reciprocating clippers to cut berry trusses. The heavy output of this harvester led to the development of mechanisms that would support and allow easy handling of shallow bulk bins and a suitable box-filling system (L auro

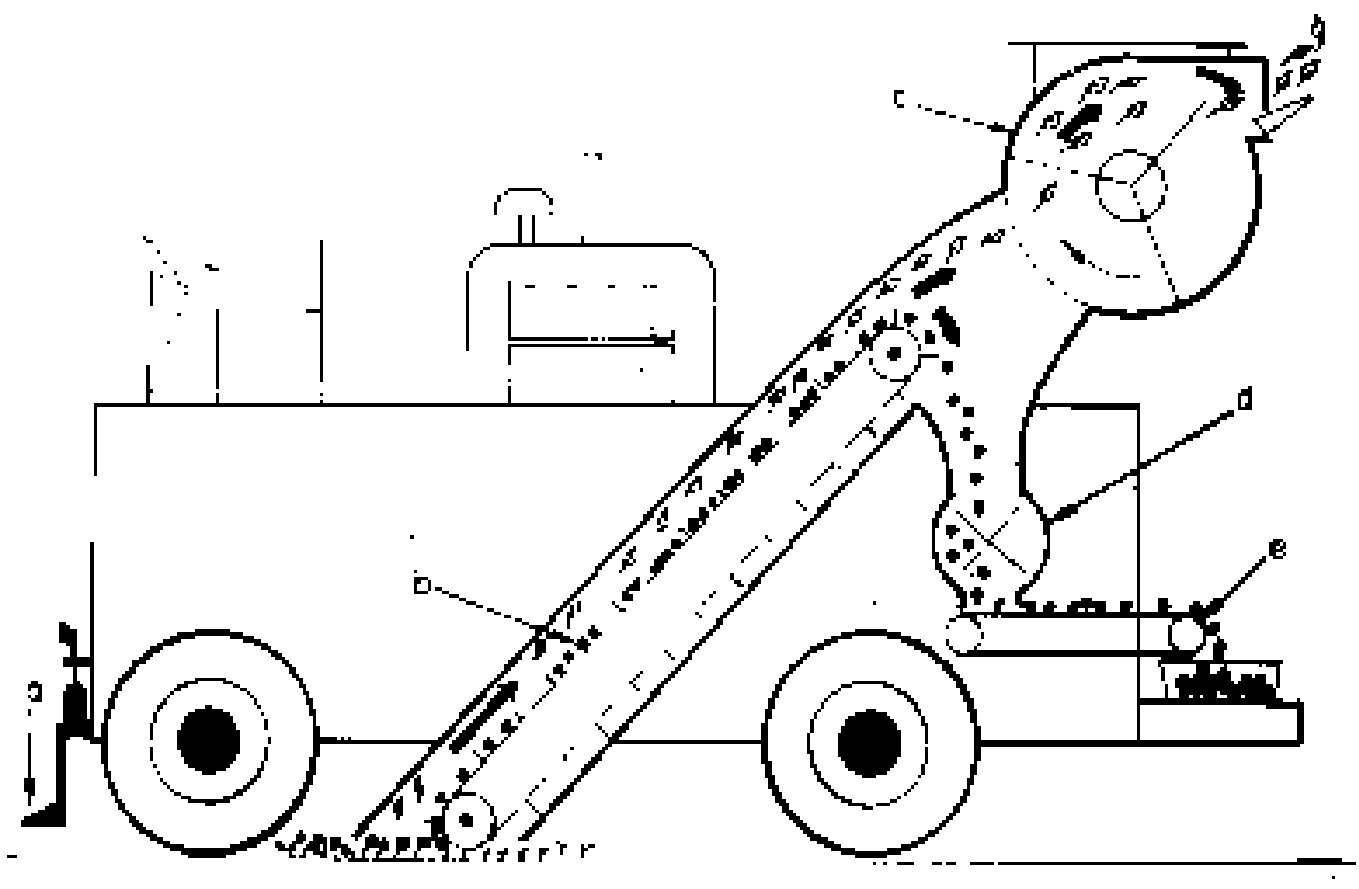
and $\mathrm{H}$ ergert, 1987). Researchers in Arkansas (Booster, 1973), O regon (H echt, 1980) and Germany (Fiedler, 1987) developed similar harvesters, although the German machine used people seated on the harvester to sort and destem the fruit.

Research at the $U$ niversity of Arkansas has shown that certain strawberry cultivars are more adapted to machine harvesting, cleaning, and sorting without loss of quality (M orriset al., 1978c, 1979c, 1980; N elson et al., 1979). Q uality of machine-harvested fruit from certain strawberry cultivars is improved by prior handpicking (M orris et al., 1979c, 1980). O nce-over machine harvested strawberries, after one or two hand harvests, have had a higher percentage of ripe berries than fruit machine harvested without a previous hand harvest. The percentage of total soluble solids, firmness, and color intensity of the once-over harvested strawberries after one or two hand pickings was the same or higher than that of hand-harvested fruit (M orris et al., 1980). Sensory qual ity of fruit puree from both machine-harvested and hand picked fruit was rated as acceptable.

O ne of the most objectionable aspects of machine-harvested strawberries is the presence of green, immature fruit. $M$ any immature berries can be separated from mature fruit in the processing plant, based on fruit size. $\mathrm{H}$ owever, large green fruit that is sorted with the large ripe fruit eventually ends up in the processed product. Research has shown that strawberry products made from cultivars containing high anthocyanin levels can tolerate as much as $50 \%$ immature fruit in the production of commercially acceptable jam (M orris et al., 1979a; Sistrunk and M orris,
1978). Strawberry jam made from 'C ardinal' strawberries, which have extremely high anthocyanin levels, can contain as much as $75 \%$ large immature fruit and still be rated acceptable (Spayd and M orris, 1981).

Strawberries are highly perishable. Research has shown that extremely firm-fruited strawberries for processing can be mechanically harvested, properly cleaned and handled, and then held for up to $48 \mathrm{~h}$ at $75^{\circ} \mathrm{F}\left(24^{\circ} \mathrm{C}\right)$ and up to $7 \mathrm{~d}$ at $35^{\circ} \mathrm{F}\left(1.7^{\circ} \mathrm{C}\right)$ without excessive quality loss ( $\mathrm{M}$ orris and $\mathrm{C}$ awthon, 1979). It also showed that fungicide dips before storage suppress mold growth and reduce loss of solublesolids. An acetaldehyde atmosphereand acombination of atmospheres and dips are effective in maintaining good color, freedom from browning and product acceptability of machine-harvested strawberriesheld for $72 \mathrm{~h}$ at $75^{\circ} \mathrm{F}\left(24^{\circ} \mathrm{C}\right.$ ) (M orriset al., 1979a, 1979c). H owever, these techniques havenot been commercially implemented since it has never been practical to use machine harvested fruit for the fresh market, and berries are usually processed immediately.

Currently, only onestrawberry harvester is operating commercially in Oregon. This harvester was developed by the $U$ niversity of Arkansas and manufactured by BEI (Figs. 2 and 3 ). The machine is used to strip the mature fruit remaining after one or two hand harvests. This fruit is being processed in a puree product. I mprovement in strawberry cultivars that would make them better suited for once-over harvest or better suited for multipleharvest, or improvements in harvesting machines will be required before large scale mechanization of strawberries will be used.
Fig. 3. U niversity of Arkansas mechanical strawberry harvester: (a) mowing sickle bar, (b) comb-brush picking and conveying system, (c) fan, (d) airlock valve, and (e) fruit transporting conveyor. 


\section{Grapes}

$M$ ajor developments in juice and wine grape harvest mechanization occurred in the early and mid-1960s (O Imo, 1980; Shepardson and M iller, 1962; Shepardson et al., 1969; Studer and $O$ (mo, 1969), and mechanization was practiced commercially by the late 1960s (J ohnson, 1977; M arshall et al., 1972). M echanically harvested grapes can have better quality than handharvested grapes when delivered promptly to the processing unit (Whittenberger et al., 1971). T rellising systems suited for mechanical harvesting and other mechanical operations continue to be a major prerequisite to successful harvesting of grapes.

Harvesters. Basically, there are two configurations of mechanical harvesters, tractor drawn and self propelled. Cattell (1994) reported that the towed models cost between $\$ 40,000$ and $\$ 75,000$. These units can generally be justified when the price of hand harvesting is between $\$ 8,000$ to $\$ 10,000$ ayear. Thesetowed units can easily handle 120 acres (48.6 ha) per season. Often, the overriding factor in a decision to purchase a harvester is to have total control over when grapes are harvested.

The self-propelled machines straddle the row and cost between $\$ 120,000$ and $\$ 150,000$. They can harvest over 247 acres (100 ha) in the course of a season. G rape growers with more than 100 acres (40.5 ha) usually consider theself-propelled units. Since these units have alarger capacity, some growers do custom harvesting as a side line. In the large grape-producing ar-

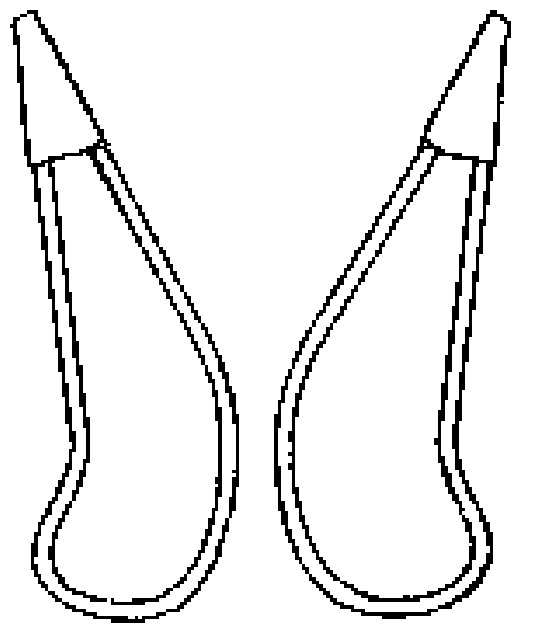

Fig. 4. B ow rods inserted horizontally in the picking field. eas of California, some companies do nothing but custom grape harvesting. These companies use only the overthe-row harvesters. These harvesters can be converted to harvest either a single-wire trellis or a divided doublecurtain trellis, which containstwo separate foliage canopies.

$M$ any of the commercial harvesters use pivotal strikers, arranged as a doublebank of flexiblehorizontal rods, that strike and shake the vine to remove fruit. They can be operated as in phase or out of phase. In phase means both the front and rear strikersmovein the same direction at the same time. This can cause vibrations, which need to be balanced by counter weights. Vibrations are not a problem with the out-of-phase pivotal strikers (the type on most older models). H owever, depending on the vinegrowth, they may not pick as well. Conversion kits are readily available to convert the out-ofphase to an in-phase system.

Another principleused in C alifornia is the trunk shaker in which two parallel rails impart horizontal vibration to the upper trunk and/ or cordon. The trunk shaker ismost effective in removing fruit located close to a rigid trunk or cordon, and much less material other than grapes, such as bark, canes, leaves, and petioles, is harvested compared to that with the pivotal striker. Some machines have combined the two principles and reduced the number of horizontal rods.

Another picking head is the bow head or bow rod unit. Construction may vary from manufacturer to manufacturer, but the shaking elements are round commercial plastic bar stock 1 to 1.5 inches $(2.5$ to $3.8 \mathrm{~cm})$ in diameter and $\approx 5 \mathrm{ft}(1.5 \mathrm{~m})$ long having the general shape of a closed shepherd's staff (Fig. 4). These horizontally oriented barsmovetransversely and shake the vine. The shaking action on the leaves is more gentle than with pivotal striker rods, and the longer striking distance resultsin less defoliation. The bow head also allows for greater harvesting speed. Because of the introduction of the bow head, the trunk shaker is not as popular in California vineyards as it was in the 1980s.

GraPe QUaLITY. The mechanical harvester makes it possible to harvest at night and the advantages of night harvesting cannot be over emphasized.

Grapes harvested at night when temperatures are more favorable for deliv- ery of cooler grapes, result in better quality than grapes harvested in the heat of the day. Research has shown that any type of grape harvested when fruit temperature is high $\left(86^{\circ} \mathrm{F}\right.$ or 30 ${ }^{\circ} \mathrm{C}$ and above) will have poor color and produce high levels of alcohol and acetic acid, both of which are signs of microbial spoilage(M orriset al., 1972). The alcohol and acetic acid levels of mechanically harvested grapes begin to rise after $12 \mathrm{~h}$ from the time of harvest if grape temperature at harvest is as high as $85^{\circ} \mathrm{F}\left(29^{\circ} \mathrm{C}\right)$. D ecreases in solublesolids, flavor, and color quality parallel the increases in alcohol and acetic acid (Benedict et al., 1968; M orris et al., 1979b). O ff-flavors are present in the processed juice product when alcohol levels seach $0.05 \%$. These studies suggest that grapes produced in hot areas, such as the San Joaquin $V$ alley of California and the southern $U$ nited States, should be harvested during cool periods of the day or at night to minimize loss of quality (Benedict et al., 1968, 1973; J ohnson, 1977; M orris et al., 1979b.)

Adding sulfur dioxide $\left(\mathrm{SO}_{2}\right)$ to machine-harvested wine grapes minimizes quality loss during holding (Benedict et al., 1973; Bourne et al., 1963; Christensen et al., 1973; M orris et al., 1972, 1979b; O'Brien and Studer, 1977). An applicator is commercially available that will meter a spray solution of $\mathrm{SO}_{2}$ onto the grapes before they enter the bins and is employed principally on wine grapes. Addition of 80 to 160 ppm SO ${ }_{2}$ immediately after harvest has been shown to slow postharvest deterioration of machine-harvested juice grapes by reducing browning and delaying alcohol accumulation and loss of solublesolids for $24 \mathrm{~h}$ (M orris et al., 1979b).

Collection and handing. M echanical harvesters havetwo basic kinds of mechanismsfor collecting thegrapes: a belt system and a bucket system. $G$ rapes that are juiced during harvesting are better handled with the bucket system. H owever, thebow rod picking head harvests more intact fruit causing less juicing than the fiberglass rods of the pivotal striker head.

The initial containers used for hauling 'Concords' and other juice grapes to the processing unit were 1 ton $(0.9 \mathrm{t})$ capacity wooden bins with food-grade plastic liners. $M$ any operations have switched to the west coast method, where 4 to 5 ton (3.6 to 4.5 
t) capacity, hydraulic, self-dumping vineyard gondola is used to transfer harvested wine or juice grapes into open-top, bulk tank trucks.

GUIDELINES FOR EFFICIENT MECHANICAL HARVESTING. Researchers at the U niversity of A rkansas in cooperation with commercial grape growers have developed guidelines for efficient mechanized harvesting and handling: 1) Select the proper revolutions per min (rpm) of the shaking mechanisms or strikers and the proper ground speed for each cultivar and crop load situation. 2) Establish a time limitation for each cultivar from harvesting to processing plant delivery. 3) 0 ptimizefruit temperature and $\mathrm{SO}_{2}$ usage. 4) Eliminate problems of material other than grapes (M OG). 5) C ease cultivation sufficiently before harvest to minimize dusty conditions. 6) Inspect the vineyard for foliar-feeding insects and, if necessary, apply sprays sufficiently ahead of harvest. 7) Provide a bin or conveyor inspector as part of the harvesting crew to removeM O G, to watch for plugging of cleaning fans, hydraulic leaks and mechanical failures, and to monitor $\mathrm{SO}_{2}$ application. 8) Cover harvested grapes at all times and clean the bin after each dumping. 9) Clean mechanical harvestersthoroughly with approved detergent and sanitizer as needed. 10) Install a magnet on the machine's discharge conveyor to collect staples and other iron-containing objects. These guidelines were developed for commercial harvesting of $\mathrm{Vi}$ tislabruscana $L$. in the eastern U nited States. Similar guidelines have been or should be developed for each region depending on standards established by the processors.

\section{Specialty grapes}

Muscadine GRAPEs. Muscadines, Vitisrotundifolia M ichx., are used primarily for wine, and most of these muscadine wine grapes are machine harvested. Muscadines are also sold fresh and asjuice, jams, and jelly. M uscadine grapes present a challenge for mechanical harvesting since they grow in small clusters that usually contain 6 to 24 large berries. $M$ ature berries of most muscadine cultivars do not adhere to their pedicel as do those of the bunch grapes. This makes muscadines easy to remove, but can cause the problem of fruit dropping in advance of the mechanical harvester. To prevent the loss of this over-mature fruit, an extended collecting unit has been designed that is adaptable to the front of any conventional commercial harvester (M orris, 1994). When using the over-the-row mechanical harvesters that have four sets of beater rods, the front two sets can be removed. This allows the beating action to start after the fruit to be removed has completely entered the harvester.

$M$ achine-harvested muscadines may be sorted effectively according to their density, with the denser berries falling into theriper categories ( $L$ anier and M orris, 1979). D ensity sorting is a rapid and inexpensive method of removing fruit of undesirable maturity. In the 1980 s, when N orth Carolina had a significant commercial muscadinegrapeindustry, onegrower built and successfully used thisdensity separation system. However, today the system isused primarily by scientists to evaluate cultivars and cultural systems for their suitability for once-over harvesting from the standpoint of uniform maturation.

RAISINs. M echanization of raisin harvest has been more difficult than that for other grapes. A severed-cane or harvest-pruning technique to facilitate the mechanical harvesting of ' $T h$ ompson Seedless' raisin grapes was reported by Studer and O Imo (1971, 1974). C utting the fruiting cane near the base and leaving the fruit on the trellis wires for 4 to $8 \mathrm{~d}$ until the pedicels dry allows the grapes to be harvested as single berries by any type of vibrating harvester. The individual berriesareconveyed into a hopper and then metered and spread evenly on a continuous paper strip. The single berries will dry uniformly without being turned. Thedried raisinsarepicked up by another machine, with metal fingers that run under the paper strip to guide it to revolving brushes, which sweep the raisins onto conveyors that transport them into bulk bins.

D ried-on-the-vine ( $D O V$ ) raisin production research began in Australia in the late 1950s and early 1960s (M ay and Kerridge, 1967). Parallel efforts were under way in California where the method was used on 'Black Corinth' and 'Thompson Seedless' cultivars. The efforts on D OV Z ante currants(from 'Black Corinth' grapes) were successful (Christensen et al., 1970), but the results with 'T hompson Seedless', the primary raisin grape, were disappointing due to their later maturity, higher vigor, and larger berry size (Studer and O Imo, 1973). H arvest-pruned 'Thompson Seedless' grapes dried to $25 \%$ to $35 \%$ moisture after 6 to 9 weeks of vine drying on their standard trellis systems. Attempts to speed up theD OV processincluded oleate sprays (Petrucci et al., 1974), but as in Australia, adequate emulsion spray coverage was difficult to achieve, and the final product was different from the natural 'Thompson Seedless' raisin (Striegler et al., 1996). TheD OV 'Thompson Seedless' raisin sprayed with oleate was not embraced by the consumer. In 1984, the raisin industry enthusiastical ly embraced the sprayedon-the-tray (SOT) method of raisin production after shallow consumer testing. That year the industry produced 7,745 tons $(7,048 t)$ of SOT raisins, only to have that production fall to 38 tons ( $34.6 \mathrm{t}$ ) in 1988 , because consumers did not buy them. Producers were anxious not to repeat this mistake ( $M$ alcolm, 1993).

Although the concept of DOV raisins is an old one, DOV has been given new life through research developments. In the new DOV method, raisins are not sprayed with oil. $\mathrm{N}$ ew trellising systemsand newly introduced seedless grape cultivars have made the spraying step unnecessary. Traditionally, in California, raisins are harvested in September and boxed 12 to $21 \mathrm{~d}$ later, depending on drying conditions. With the present DOV system, canes are cut in August so the chance of rain is very low.

$\mathrm{N}$ ew trellis systems have been developed for DOV production. These trellis systems follow the general principle of separating the vine canopy into fruiting and nonfruiting zones and are designed also to facilitate mechanization of harvest pruning, the cutting of fruiting canes for drying on the vine. Generally, this year's canes are on the south side of an east-west row and next year's canes are in a catching trellis system that provide for maximum sun exposure. The southern exposure gives adequate sunlight exposure and optimum drying conditions. Australia is also actively reviving the DOV system. They have introduced special ized trellising systems along the above described lines: the I rymple system (Gould and Whiting, 1987), the Shaw system (Shaw, 1986), and the swing-arm system (Clingeleffer and May, 1981). 
Another manner in which to improve the D OV system is to use specially designed seedless cultivars. Three cultivars are being investigated for use in DOV raisin production. 'Thompson Seedless $2 A$ ' is aheat-treated, virus-free clone of 'Thompson Seedless'. It has a proven track record of productivity and is preferred for new plantings of 'T hompson Seedless' for raisins and crushing. 'Fiesta' is a result of a complex cross made in the 1960s at the U SDA H orticultural Field Station in Fresno, Calif. It ripens 10 to 14 d earlier than 'Thompson Seedless', produces high quality raisins and, after initial concerns over seed traces were laid to rest, has gained supporters in the last several years [3,840 acres $(9,489$ ha) in 1996] (Christensen, 1997). 'D O Vine' is a recent (1995) release by $D$ avid $R$ amming ( $U$ SD A) as an early ripening ( 2 to 3 weeks before 'Thompson Seedless') cultivar that is suitable for DOV production (C hristensen, 1997). 'D O Vine's' high vigor provides potential for alargevine framework and a canopy adapted to more expansive trellising and the demands of cane renewal for D O V. I n fact, its greatest potential is with large, expansive D O V trellis systems where the canopy can be spread. Vigor control through controlled drip irrigation and nitrogen fertilization will be necessary in most sites. Vertical or south side systems may not handlethe vigor unless these control measures are taken.

All three of these cultivars show appropriate fruitfulness characteristics for DOV. In comparative studies done at the California Kearney Agricultural Research and Extension Center, raisin yields were statistically similar among the cultivars. Berry weights were heaviest with 'Fiesta', followed by 'D O Vine' and 'Thompson Seedless $2 A^{\prime}$. A irstream sorter raisin grades were similar, except the percentage of substandard berries was higher in 'D O Vine' than in 'T hompson Seedless 2A'. R esearchersconcluded that 'Thompson Seedless' (the 2A clone) will continue to be a dominant cultivar because of its adaptability, versatility,

Table 1. Effect of thinning double curtain 'C oncord' grapes grown at Merritt Vineyard, N.Y, 1997. Source: Joint research by M orris, M ain, and Dunst funded by N ew York State Agricultural Experiment Station Viticulture C onsortium R esearch G rants Program.

\begin{tabular}{|c|c|c|c|c|}
\hline Treatment & $\begin{array}{c}\text { Yield } \\
\text { (tons/ acre) }\end{array}$ & $\begin{array}{c}\text { Soluble } \\
\text { solids } \\
(\%)\end{array}$ & $\mathrm{pH}$ & $\begin{array}{c}\text { Red } \\
\text { pigment } \\
(520 \mathrm{~nm})\end{array}$ \\
\hline Control & $13.5 a^{2}$ & $12.7 \mathrm{c}$ & 3.24 & $4.04 c$ \\
\hline$C-R^{y} 250 \mathrm{rpm}$ & $9.9 b c$ & $14.2 \mathrm{~b}$ & 3.27 & $6.01 \mathrm{~b}$ \\
\hline $\mathrm{M}-0^{\times} 200 \mathrm{rpm}$ & $11.5 \mathrm{ab}$ & $13.7 \mathrm{~b}$ & 3.28 & $4.71 b c$ \\
\hline M-O $225 \mathrm{rpm}$ & $11.0 \mathrm{bc}$ & $14.4 \mathrm{~b}$ & 3.27 & $6.08 \mathrm{~b}$ \\
\hline M-O 250 rpm & $9.2 \mathrm{c}$ & $15.2 \mathrm{a}$ & 3.25 & $8.15 \mathrm{a}$ \\
\hline
\end{tabular}

$z_{M}$ eans within the same column having the same letters are not significantly different at $\alpha \leq 0.05$.

${ }^{y} C$ hisholm-Ryder harvester for thinning.

$\mathrm{x}_{\mathrm{M}}$ orris-O Idridge thinning unit. familiarity, and longevity (C hristensen, 1997). Industry leaders believe the D OV technique has potential for saving money while improving their operation and producing high-quality raisins. The new DOV systems eliminate pickers, turners, rollers, the traditional boxing crew, and even paper trays. There will be savings in crop insurance as it is presently written and on workers' compensation. Estimates of savings run as high as $\$ 300 /$ acre (2.5 ha) with D OV production (M alcolm, 1993).

In 1992, one prototype harvester for D O V production was designed and manufactured by Ag Right Enterprises of M adera, $C$ alif. The unit is operated by hydraulics and uses a radial-forced balanced shaker unit that gently knocks the raisins off the canes into a catcher with a conveyor belt that takesit up to another conveyor unit that deposits the raisins into a bin trailer running in the adjacent row, parallel to the machine. Another prototype harvester system that is currently being evaluated is manufactured by Korvan Industries, Inc., O re.

More time is needed to evaluate the most cost effective trellis systems, handling, and processing. H owever, industry is concerned about market analysesand the public's acceptance of the characteristics of DOV raisins. In 1993, one raisin board adopted a long-term policy of gradual market development ( $\mathrm{M}$ alcolm, 1993).

\section{Other mechanization practices for grapes}

Pruning and thinning. Along with mechanical harvesting, other mechanized processes can improve efficiency in grape production. M echanical pruning can reducehand labor by as much as 50\% Studies in Arkansas on shoot-positioned 'Concord' grapevines trained to G enevaD ouble C urtain (GDC), (a system with two adjacent wires $\approx 4 \mathrm{ft}(123 \mathrm{~cm})$ apart with vines trained on them to form a double curtain of foliage) or bilateral cordon systems (which have one wire with vine cordons running up and down forming a single curtain of foliage) examined the effects of mechanical pruning on yield, vine size, and juice quality. The results showed that continual mechanical pruning of 'C oncord' grapes is recommended only in shoot-positioned vineyards where cane selection and adequate node, shoot or fruit limitation follows pruning. Recent data from the author show that mechanical fruit thinning also eliminates the problem of overcropping without the need for hand thinning. D ata collected in a commercial vineyard in N ew York in 1997 showed that it was possible to mechanically thin a machine-pruned vineyard with the M orris- 


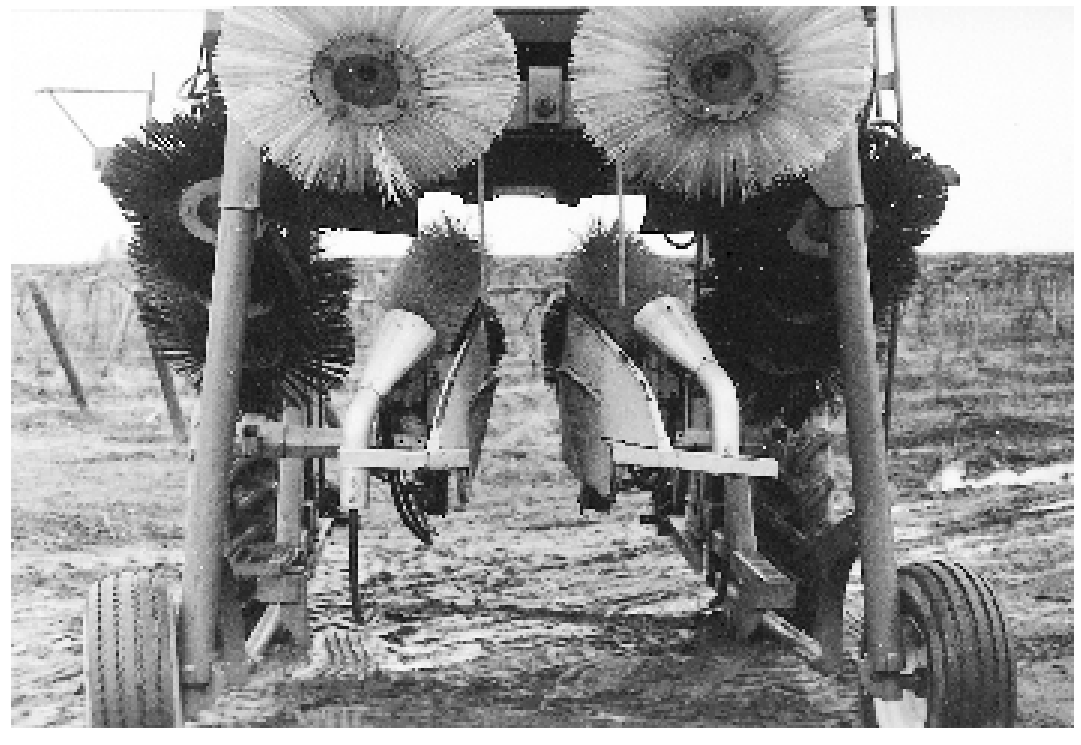

Fig. 5. A G eneva double curtain over-therow mechanical shoot positioner developed by T om Oldridge, L owell, Ark. Adding cutter bars behind converts the machine to a mechanical pruner. These units are used as part of one of the 12 Morris-Oldridge vineyard mechanization systems.

Oldridge thinning unit at $250 \mathrm{rpm}$ and obtain high quality ( $15.2 \%$ soluble solids) 'Concord' juice grapes (Table 1).

Sноот Positioning. Shoot positioning allowsfor effectivemechanical pruning. Shoot positioning of the canes to avoid shading exposes the lower nodes on the bearing units to sunlight, making these basal nodes more productive, and improving fruit quality (M orris et al., 1984). Positioning is particularly effective on the vigorousV. Iabruscana cultivars. Vines are usually shoot positioned for the first time at first bloom, but complete shoot positioning usually requires a second and possibly a third pass (Fig. 5). A properly shoot-positioned G D C system with two separate foliage cano pies is more efficient to harvest mechanically than a nonpositioned canopy. A bilateral or single-curtain system that has been shoot positioned is easier to mechanically prune and mechanically harvest with less damage

to fruit and canes.

Completely MECHANIZED SYSTEMS FOR GRAPES. In a cooperative research effort the author and Tom Oldridge, grape grower and inventor from Lowell, Ark, have developed systems for vineyard mechanization, and we have a pending patenton vineyard machinery and systems. TheM orris-Oldridge Systems provide machines that allow for almost complete mechanization of all vineyard operations. The patent describes a method for complete vineyard mechanization of 12 different trellising systems and methods to modify, trellis, and train grapevines. These developments eliminate expensive hand operations, and production can be economically mechanized without any substantial loss of yield or fruit quality. This patent is the result of studies at the $U$ niversity of A rkansas over the last 32 years that have involved the evaluation of trellising and training systems suitable for complete vineyard mechanization, mechanical shoot positioning, mechanical pruning, mechanical thinning (Tables 1 and 2), mechanical harvesting, and the postharvest handling and use of mechanically harvested grapes (Cawthon and M orris, 1977; M orris, 1985; M orris and Cawthon, 1980a, 1980b, 1981; M orris et al., 1975, 1984).

Currently, two trellising systems can be completely mechanized-the GDC and the single curtain system. In addition, variations of thesesystemscan also be completely mechanized. We have designed a complete mechanization system with the apparatusand methods for the mechanization of, not only the juice grapes of Vitislabruscana species, but

Table 2. Effect of thinning and pruning methods on yield and fruit quality of 'C abernet Sauvignon' grapes grown at Vino Farms, I nc., L odi, C alif., 1997.

\begin{tabular}{|c|c|c|c|c|c|c|}
\hline $\begin{array}{l}\text { Pruning } \\
\text { treatment }\end{array}$ & $\begin{array}{l}\text { Thinning } \\
\text { treatment }\end{array}$ & $\begin{array}{c}\text { Yield } \\
\text { (tons/ acre) }\end{array}$ & $\begin{array}{c}\text { Soluble } \\
\text { solids } \\
(\%)\end{array}$ & $\mathrm{pH}$ & $\begin{array}{c}\text { Tartaric } \\
\text { acid } \\
(\%) \\
\end{array}$ & $\begin{array}{c}\text { Anthocyanin } \\
\left(\mathrm{mg} / \mathrm{cm}^{3}\right)\end{array}$ \\
\hline Spur pruned control & None & $11.4 b^{2}$ & $25.2 \mathrm{bcd}$ & 3.78 & $0.54 a b c$ & $0.30 \mathrm{bc}$ \\
\hline M achine & None & $15.0 \mathrm{a}$ & $23.7 \mathrm{de}$ & 3.60 & $0.57 \mathrm{a}$ & $0.31 \mathrm{bc}$ \\
\hline M achine & $\mathrm{M}-\mathrm{O}^{\mathrm{y}}(400 \mathrm{rpm})$ & $8.5 \mathrm{c}$ & $26.6 \mathrm{ab}$ & 3.72 & $0.51 \mathrm{bc}$ & $0.39 a b$ \\
\hline M inimal & None & $15.2 \mathrm{a}$ & $22.4 \mathrm{e}$ & 3.52 & $0.59 a$ & $0.26 \mathrm{c}$ \\
\hline M inimal & M-O (600 rpm) & $10.8 b c$ & $25.2 \mathrm{bcd}$ & 3.63 & $0.55 a b$ & $0.37 a b$ \\
\hline
\end{tabular}

${ }_{\mathrm{z} M}$ eans within the same column having the same letters are not significantly different at $\alpha \leq 0.05$.

yM orris-O ldridge thinning unit. 
T able 3. Effect of leaf removal method on rot, yield, and quality of ' $\mathrm{C}$ hardonnay' grapes grown at White H ills Vineyard, Santa M aria, C alif, 1997. Source: Striegler and Berg, Viticulture Enology R esearch Center, California State University, Fresno.

\begin{tabular}{lccccc}
\hline Treatment & $\begin{array}{c}\text { Rot } \\
(\%)\end{array}$ & $\begin{array}{c}\text { Yield } \\
\text { (tons/ acre) }\end{array}$ & $\begin{array}{c}\text { Soluble } \\
\text { solids } \\
(\%)\end{array}$ & pH & $\begin{array}{c}\text { Tartaric } \\
\text { acid } \\
(\%)\end{array}$ \\
\hline N o Leaf Removal & $26.5 \mathrm{a}^{2}$ & 4.4 & 23.3 & 3.51 & 0.85 \\
H and Removal & $10.6 \mathrm{~b}$ & 5.7 & 22.8 & 3.52 & 0.77 \\
M - O no hand followup & $12.4 \mathrm{~b}$ & 5.5 & 23.3 & 3.56 & 0.79 \\
M-O hand followup & $16.1 \mathrm{~b}$ & 5.4 & 23.7 & 3.52 & 0.92 \\
\hline
\end{tabular}

${ }^{2} M$ eans within the same column having the same letters are not significantly different at $\alpha \leq 0.05$.

yM orris-O ldridge thinning unit.

also Vitis vinifera $L$. and FrenchAmerican hybrids (Vitis interspecies hybrids). The French-American hybridsare interspecific hybrids that vary a great deal in their vine characteristics. Almost all hybrids tend to be extremely fruitful. This fruitfulness is due primarily to the high number of clusters per node and the extremely fruitful basal nodes. These basal nodes are seldom, if ever, fruitful with $V$. labruscana and $V$. vinifera species.

$\mathrm{H}$ and thinning of French-A merican hybrid vineyards is conducted in the traditional manner to ensure a sustainable fruit load that produces consistently high quality fruit from these cultivars. $\mathrm{H}$ owever, hand thinning is expensive and one of the greatest challenges in producing these cultivars. Mechanical thinning is both economical and successful on these hybrids. M echanical removal of basal leaves in V. vinifera has successfully reduced fruit rot (T able 3 ) from $26.5 \%$ to $16.1 \%$ on 'C hardonnay' grapes at Santa M aria, Calif., in 1997. Removal of leaves by hand did not significantly reduce rot over machine removal, and the cost of hand removal was estimated at $\$ 120 /$ acre (2.5 ha).

M ost premium wines produced in the world comes from $V$. vinifera grapes. Wineries pay premium prices for high quality vinifera grapes. In some regions, the crop must be limited, and leaf removal is practiced to produce a specific quality, and in others, the crop must belimited to ensure maturity due to a shortened growing season. Also, crop adjustment is used in many graperegions of the world and is even enforced by law in some. These are expensive operations when carried out with hand labor. By mechanizing these operations, grape production for premium wine production should become more profitable.

\section{Conclusions}

In brambles and strawberries as well as grapes, mechanization can improve efficiency, but wise use of such mechanization requires careful adaptations to specific crops and sometimesto specific cultivars. For example, although complete vineyard mechanization systems and methods provide the viticulturist with a wide array of tools, careful useand intelligent implementation of each of these tools must be understood for the systems to be successful. Further research and continued improvement in mechanized practices will make completely mechanized systems more efficient. Adoption of completely mechanized systems can potentially mean more reliable, more stable and more economical production of premium quality fruit that will be competitive for the local, regional, national and global markets.

\section{Literature cited}

Benedict, R.H ., J.W. Fleming, and M.D.Jones. 1968. Q uality of machine-harvested grapes. Ark. Farm Res. 17(2):10.

Benedict, R.H ., J.R. M orris, J.W. Fleming, and D.R. M cC askill. 1973. Effects of temperature on quality of mechanically harvested 'Concord' grapes. Ark. Farm Res. 22(1):2.

Booster, D.E. 1973. The mowing method of harvesting strawberries. Amer. Soc. Agr. Eng. Paper 73-109.

Booster D.E., D.E. Kirk, G.W. Varseveld, and T.B. Putnam. 1970a. M echanical harvesting and handling of strawberries for processing. Amer. Soc. Agr. Eng. Paper 70-670.

Booster D.E., G.W. Varseveld, and T.B. Putnam. $1970 \mathrm{~b}$. Progress in the mechanization of strawberry harvesting. O regon State U niv. Agr. Expt. Sta. Spec. Rpt. 305

Bourne, M .C., D.F. Splittstoesser, L.R. M attick, W.B. Robinson, J.C. M oyer, N.J. Shaulis, and E.S. Shepardson. 1963. Product quality and me- chanical grape harvesting. Proc. N.Y. StateH ort. Soc., Geneva. p. 227-230.

Cattell, H. 1994. Considerations in buying a mechanical harvester. Wine East's 1994 buyer's guide to winery and vineyard equipment and supplies. p. 26-28.

Cawthon, D.L. and J.R. M orris. 1977. Yield and quality of 'C oncord' grapes as affected by pruning severity, nodes per bearing unit, training system, shoot positioning, and sampling date in Arkansas. J. Amer. Soc. H ort. Sci. 102:760-767.

Christensen, L.P. 1997. H ow do Thompson Seedless, Fiesta, and DOVine compare in new raisin vineyard planting decisions? Proc. San J oaquin ValleyG rapeSymp. U niv. of Calif, Fresno.

Christensen, P., C. Lynn, H .P. O Imo, and H .E. Studer. 1970. Mechanical harvesting of Black Corinth raisins. Calif. Agr. 24(10):4-6.

Christensen, L.P., A.N . Kasimatis, J.J . Kissler, F. Jensen, and D.A. Luvisi. 1973. M echanical harvesting of grapes for the winery. Calif Agr. Ext. Bul. AXT-403.

Crandall, P.C., C.H . Shanks, J r., and J E. G eorge, Jr. 1966. M echanically harvesting red raspberries and removal of insects from the harvested product. Proc. Amer. Soc. H ort. Sci. 89:295-302.

Clingeleffer, P.R. and P. M ay. 1981. The swingarm trellis for Sultana grapevine management. S. Afr. J. Enol. Viticult. 2(2):37-44.

Dale, A., E.J. H anson, D.E. Yarborough, R.J. $\mathrm{M} \mathrm{CN}$ icol, E.J. Stang, R. Brennan, J.R. M orris, and G.B. H ergert. 1995. M echanical harvesting of berry crops, p. 255-367. In: J. Janick (ed.). $\mathrm{H}$ orticultural reviews. vol. 16. Wiley, N ew York.

Denisen, E.L. and W.F. Buchele. 1967. Mechanical harvesting of strawberries. Proc. Amer. Soc. H ort. Sci. 91:267-273.

Di Ciolo, S. and M. Zoli. 1975. Strawberry mechanical harvest with a prototype experimental harvester. Riv. Ing Agrar. 6:3-8.

Fiedler, W. 1987. Entwicklung eines verfarhens der maschinellen erdbeernte und erste einsatzerfahrungen. Arch. Gartenbau. 35:379391.

Gould, I.V. and J.R. Whiting. 1987. M echanization of raisin production with the I rymple trellis system. Trans. Amer. Soc. Agr. Eng. 1987. p. 5660.

H ansen, C.M ., R.L. L edebuhr, R.L. Van Ee, and O. Friesen. 1983. Systems approach to strawberry harvest mechanization. Fruit, N ut Veg. $\mathrm{H}$ arvest $\mathrm{M}$ ech. (Amer. Soc. Agr. Eng.) 5-84:325331.

H echt, C. 1980. 1979-The proving year of the SKH \& S harvester of strawberries in Oregon. O regon State U niv. (Corvallis) Agr. Expt. St. Bul. 645. p. 239-240.

Johnson, S.S. 1977. M echanical harvesting wine grapes. U SD A E con. Res. Serv. Agr. Econ. Rpt. 385.

Kemp, I. 1976. M echanical harvesting of strawberries. N.Z. J. Agr. 132:54, 57-58. 
Lanier, M .R. and J.R. M orris. 1979. Evaluation of density separation for defining fruit maturities and maturation rates of once-over harvested muscadine grapes. J. Amer. Soc. H ort. Sci. 104:249252.

L auro, E.M . and G.B. H ergert. 1987. Evaluating the technical and economic feasibility of machine harvesting strawberries. Can. Soc. Agr. Eng. Paper 87-206.

L ucignani, M . 1979. Study and design of a new prototype of strawberry harvester working aside the row. Riv. Ing. Agar. 10:23-34

M alcolm, D. (ed.). 1993. N ew drying and harvesting process developed for raisins: Sun-M aid develops dried-on-vine process. Amer. Vineyard 2(9):4-5, 20-21.

M arshall, D.E., J.H . L evin, B.F. Cargill, and R.T. Whittenberger. 1972. Q uality of bulk handled 'Concord' grapes. Presented at the 1972 Ann. $\mathrm{M} \mathrm{tg.} \mathrm{Amer.} \mathrm{Soc.} \mathrm{Enol.,} \mathrm{U} \mathrm{niv.} \mathrm{of} \mathrm{Calif.,} \mathrm{D} \mathrm{avis.}$

M ay, P. and G.H . Kerridge. 1967. H arvest pruning of Sultana vines. Vitis 6:390-393.

M oore, J.N . 1979. Small fruit breeding-A rich heritage, a challenging future. $\mathrm{H}$ ortScience 14:333-341.

Moore, J.N. 1984. Blackberry breeding. H ortScience 19:183-185.

Morris, J.R. 1994. M echanical harvesting and vineyard mechanization. WineE ast's 1994 buyer's guide to winery and vineyard equipment and supplies. p. 4-23.

M orris, J.R. 1985. A pproaches to more efficient vineyard management. H ortScience20(6):10081013.

M orris, J.R. and D.L. Cawthon. 1979. Postharvest quality of machine-harvested strawberries. J. Amer. Soc. H ort. Sci. 104:138-141.

Morris, J.R. and D.L. Cawthon. 1980a. Mechanical trimming and node adjustment of cordon-trained 'C oncord' grapevines. J. Amer. Soc. H ort. Sci. 105(3):310-313.

M orris, J .R. and D.L. Cawthon. 1980b. Yield and quality response of ' $C$ oncord grapes to training systemsand pruning severity in Arkansas. J. Amer. Soc. H ort. Sci 105(3):307-310.

M orris, J.R. and D.L. Cawthon. 1981. Yield and quality response of ' $C$ oncord grapes(Vitislabrusca L.) to mechanized vine pruning. Amer. J. Enol. Viticult. 32:280-282.

M orris, J.R., J.W. Fleming, R.H . Benedict, and D.R. M cC askill. 1972. M aintaining juice quality of 'C oncord' grapes harvested mechanically. Ark. Farm Res. 22(1):3.

M orris, J.R., D.L. Cawthon, and J.W. Fleming 1975. Effect of mechanical pruning on yield and quality of 'Concord grapes. Ark. Farm Res. 24(3):12.

Morris, J.R., D.L. Cawthon, G.S. N elson, and P.E. Cooper. 1978a. Effect of daminozide and ethephon on yield and quality of erect blackberries. J. Amer. Soc. H ort. Sci. 103:804-806.
M orris, J.R., G.S. N elson, A.A. Kattan, and D.L. Cawthon. 1978b. D eveloping amechanized harvesting and production system for erect blackberries. H ortScience 13(3):228-235.

M orris, J.R., A.A. Kattan, G.S. N elson, and D.L. C awthon. 1978c. D eveloping a mechanized system for production, harvesting and handling of strawberries. H ortScience 13:413-422.

M orris, J.R., D.L.C awthon, and R.W. Buescher 1979a. Effects of acetaldehyde on postharvest quality of mechanically harvested strawberriesfor processing. J. Amer. Soc. H ort. Sci. 104:262264.

M orris, J.R., D.L. C awthon, and J.W. Fleming 1979b. Effects of temperature and $\mathrm{SO}_{2}$ addition on quality and postharvest behavior of mechanically harvested juice grapes in Arkansas. J. Amer. Soc. H ort. Sci. 104:166.

M orris, J.R., G.S. N elson, D.L. Cawthon, and R.W. Buescher. 1979c. Acetaldehyde effects on postharvest quality of machine-harvested strawberries. Ark. Farm Res. 28(3):10.

Morris, J.R., S.E. Spayd, D.L. Cawthon, A.A. Kattan, and G.S. N elson. 1980. Response of seven strawberry clones to hand picking prior to once-over machine harvest, p. 15-24. In: L. $M$ artin and J.R. M orris(eds.) Strawberry mechanization. O regon State U niv. Expt. Sta. Bul. 645.

M orris, J.R., D.L. Cawthon, and C.A. Sims. 1984. Long-term effects of pruning severity, nodesper bearing unit, training system and shoot positioning on yield and quality of 'Concord' grapes. J. Amer. Soc. H ort. Sci. 109(5):676683.

N elson G.S. and A.A. Kattan. 1967. A mechanical harvester for strawberries. Ark. Farm Res. 16(4):2.

N elson G.S., J.R. M orris, A.A. Kattan, and K.P. Shelby. 1978. M echanical system for harvesting and handling strawberries for processing. Trans. Amer. Soc. Agr. Eng. 19:21-26.

Nelson, G.S., J.R. Morris, and K.P. Shelby. 1979. In-plant equipment for handling machineharvested strawberries. Ark. Farm Res. 25(6):8.

O'Brien, M . and H .E. Studer. 1977. Closed and open transport and sampling of wine grapes. Trans. Amer. Soc. Agr. Eng. 20:631.

O Imo, H .P. 1980. M echanical harvest of grapes p. 187. In: U niv. Calif. Davis Grape and Vine Centennial Symp. Proc.

Petrucci, V.E., N . Canata, H .R. Bolin, G. Fuller, and A.E. Stafford. 1974. U se of oleic acid derivatives to accelerate drying of Thompson Seedless grapes. J. Amer. O il Chem. Soc. 51(3):77-80.

Q uick, G. R. and E.L. Denison. 1970. A strawberry harvest mechanization system. $\mathrm{H}$ ortScience 5:110-151.

Rosati, P. 1980. M echanization of the Italian strawberry industry. O regon State U niv. (Corvallis) Agr. Expt. Sta. Bul. 645. p. 66-69

Shaw, I . 1986. D evelopment of specialized trellis drying systems. $\mathrm{H}$ anging cane, p. 93-94. In: I. Ballantyne and I. M acrae (eds.). Trellis drying and mechanical harvesting of grapes. Dept. of Agr. Rural Affairs, Conf. Proc. Ser. 7.

Shepardson, E.S. and W.F. M iller. 1962. Progress report: M echanical grapeharvester research. N.Y. State Agr. Expt. Sta. (Geneva) Res. Rpt.

Shepardson, E.S., N .J . Shaulis, and J.C. M oyers. 1969. M echanical harvesting of grape varieties grown in N ew York State, p. 571. In: B. Cargill and A. Rossmiller (eds.). Fruit and vegetable harvest mechanization. Rural $\mathrm{M}$ anpower $\mathrm{C}$ enter, $M$ ich. State U niv., E ast L ansing.

Shikaze, A. and D.R. N yborg. 1973. M echanical strawberry harvester trials. Can. Soc. Agr. Eng. Paper 73-320.

Sims, C.A. and J.R. M orris. 1982. Effects of cultivar, irrigation, and ethephon on the yield, harvest distribution, and quality of machineharvested blackberries. J. Amer. Soc. H ort. Sci. 107:542-547

Sistrunk, W.A. and J.R. M orris. 1978. Storage stability of strawberry products manufactured from mechanically harvested strawberries. J. Amer. Soc. H ort. Sci. 103:616-620.

Spayd, S.E. and J.R. M orris. 1981. Physical and chemical characteristics of puree from once-over harvested strawberries. J. Amer. Soc. H ort. Sci. 106:105-109.

Striegler, R.K., J.R. M orris, and G.T . Berg. 1996. Raisin production and processing, p. 235-265. In: L. Somogyi (ed.) Processing fruits: Science and technology. vol 2. Technomic Publ., Lancaster, $\mathrm{Pa}$.

Studer, H.E. and H.P. O Imo. 1969. M echanical harvesting of grapes in California: Cultural practices and machines, p. 611-625. In B. Cargill and A. Rossmiller (eds.). Fruit and vegetable mechanization. Rural M anpower Center, M ich. State U niv., East Lansing.

Studer, H .E. and H .P. O Imo. 1971. The severed cane technique and its application to mechanical harvesting of raisin grapes. Trans. Amer. Soc. Agr. Eng. 14:38.

Studer, H.E. and H .P. O Imo. 1973. Vine-drying of Thompson Seedless grapes. Calif. Raisin Adv. Board Raisin Res. Rpt. 1973. p. 960-970.

Studer, H .E. and H .P. O Imo. 1974. Parameters affecting the quality of machine-harvest raisins. Trans. Amer. Soc. Agr. Eng. 17:783.

Swinkles, P.M . and R.A. M urray. 1991. Development of the Bragg strawberry harvester, p. 266 In: A. D ale and J.J. L uby (eds.). The strawberry into the $21^{\text {st }}$ century. Timber Press, Portland, Ore.

Thuesen, A. 1988. M askinhost af industrijordbaer Gron Viden 141, D enmark

Whittenberger, R.T. D.E. M arshall, J.H . Levin, and B.F. Cargill. 1971. Bulk handling of 'C oncord' grapes for processing: Q uality evaluation. Presented at Annu. M tg. Amer. Soc. Agr. Eng., St. J oseph, M ich. 